\title{
A Theoretical Framework for Demystifying the Causes of Dysfunction and Disorder in the Chinese Market Economy: A Weberian Perspective
}

\author{
Huangnan Shen $\mathrm{Jim}^{1} \cdot$ XiaoJie Liu ${ }^{2}$
}

Received: 24 February 2016/Accepted: 31 May 2017/Published online: 19 June 2017

(C) The Author(s) 2017. This article is an open access publication

\begin{abstract}
This paper explores a theoretical framework for demystifying the causes of the dysfunction and disorder of the present Chinese market economy. It is posited that Max Weber's classification of the two potentially conflicting ethics he associates with the behaviour of politicians, the ethic of conviction and the ethic of responsibility offers the basis for a more thorough and accurate account of the dysfunction and disorder within China's current markets and political economy. Indeed, this paper contends that cultural determinism and neo-institutional economics fail to capture the contextual factors influencing the transition from the Maoist era of state control to contemporary China's market led economy (following the opening-up of the country since 1978) than a wider reaching Weberian analysis of the contextual factors involved might achieve. This paper proposes that the distinct ethical foundation for the Chinese market economy is based upon the ethic of conviction, which is the continuity of the philosophical underpinnings of the national ideology during the Maoist era. In turn, this has led to the distortion of the incentives for firms in China to provide high-quality goods and services. This paper also conducts a study of the ethical foundations of the present Chinese economy from the comparative perspectives of Smith's concept of the market economy and from a Confucian perspective. Through this comparative examination, it will be demonstrated that the ethical feature of the modern market economy, stemming from Smith and Confucianism, is based on the ethic of responsibility, which is a mutually opposed concept to the ethic of conviction; therefore, firms whose business ethics are founded upon the ethic of "responsibility" are less prone to deceive
\end{abstract}

Huangnan Shen Jim

h.shen1@1se.ac.uk; huangnanjim@hotmail.co.uk

XiaoJie Liu

12307130035@fudan.edu.cn

1 Department of Management, London School of Economics and Political Science, London, UK

2 Department of Economics, Sciences Po, Paris, France 
consumers as they adhere to a contractual "responsibility" towards the consumer that many Chinese firms still see as of secondary importance as the ethic of "conviction" still dominating the policies, society and culture of the centralist economic post-Maoist state. This paper further reveals that larger firms tend to have more corporate social responsibility due to their established branding effect, thus reflecting a more pervasive sense of the ethic of responsibility and vice versa for firms of a smaller size. This paper concludes with an economic model acting as a quantitative framework which further supports the theories proposed.

Keywords Moral Foundation - Chinese Market Economy · Morality of Conviction · Morality of Responsibility · Weberian Analysis

\section{Introduction}

The rapid growth of the Chinese market economy over the past 30 years has seen a huge number of instances in which the rights of consumers have been infringed by corporations: recent examples relate to poisonous milk powder (毒奶粉) and illegal cooking oil (地沟油). ${ }^{1}$ The conventional literature attempting an elucidation of such dysfunctions is mainly centred around the frameworks of cultural determinism and neoinstitutional economics; however, both frameworks fail to account for the influence of the philosophical and cultural continuum to the present day of Maoist ideology. This paper demonstrates why balancing the perspectives of cultural determinism and neoinstitutional economics with a properly contextual analysis of the sociopolitical institutions within Chinese society from the Maoist era to the post-Maoist period is crucial in demystifying the dysfunctions of China's fledgling market economy.

\section{Literature Review}

From the point of the view of cultural determinists and neo-institutional economists, the social norms or traditional values of a country largely determine the efficiency of institutions including the (market) economy and the institutions of state and legislature (North 1990; Barro and McCleary 2003, etc.). ${ }^{2}$ Likewise, Sen (1997)

\footnotetext{
${ }^{1}$ There are also other incidents. At the end of 2002, the Ministry of Health announced ten food counterfeiting: white sugar mixed with sulphur magnesium in Jinhua City; fake and bad quality duck blood in Changchun City, Jilin Province; illegally produced beef in Luohe City, Henan Province; out-ofdate beer in Suiyang District, Shangqiu City, Henan Province; the processing of rotten meat in Qingtongxia City, Ningxia Province; poor litchi preservation in Changchun City, Jilin Province; the Shanghai Nanxi Qingfeng Food Co. recycling out-of-date food; illegal sales of puffer fish in Jinan City; gluten added to smoked duck in Chongqing; and illegally purchased dog carcasses in Liaoyuan City, Jilin Province. These are noted in Deng (2011: p. 128).

${ }^{2}$ In neo-institutional economics, formal institutions refer to systems with specific regulations and rules, such as a market economy and constitutional politics. Informal institutions refer to the customs, cultural traditions and ethics of a society that have gradually evolved. Institutional economists argue that changes in the formal institutions of a country depend on the marginal evolution of its informal institutions. In other words, the evolution of informal institutions determines the effectiveness of formal institutional changes (North 1990, pp. 43-45).
} 
argued that the functioning of the market economy in developed countries relies upon some sort of moral consensus which might only be derived from a country's traditions or social norms. Empirical evidence supporting Sen's argument is clearly forthcoming in the case of advanced economies, notably Britain, the USA and Japan, who, significantly, experienced a strong religious revival before the development of their market economy; therefore, in these countries, the dysfunction of the market due to a failure of the ethic of responsibility was not as serious as in today's China (Yao 2011). A closer consideration of the case of Japan adds further weight to Sen's analysis. In Japan, one can perceive a strong sense of the mixture between traditional Confucian ethics and the role of self-interest in generating wealth in terms of the business ethic adopted by businessmen in Japan. As Huang (2015, p. 231) argued:

...in the early twentieth century Shibusawa Eichi spoke of uniting 'the scholar's integrity with the merchant's talent. In regard to the abacus, if the user based himself on the Analects, he will be more accurate. The Analects too can increase the user's output on the abacus, leading to increase in wealth. In making this assertion, Shibusawa had selected the idea with the unity of righteousness and profit in Confucius's thought.'... ${ }^{3}$

According to Morishima (1982), the Japanese government instilled the Confucian values and ethics into Japanese society both before the "opening-up" of the economic policies in nineteenth century and after the World War II. The close adherence of the Japanese government to the Confucian values could be deemed as one of the two key reasons in explaining the success of the Japanese economy after World War II, in addition to the highly effective industrialization policies. Gong (2006) thought the common point of the economic success of the East Asian "Four Little Dragons" is: "They are all deeply influenced by Confucianism and have accepted the Confucian ethics and values". MacFarquhar (1985) and Zou (1993) have also made similar arguments.

If one now attempts an explanation from the perspective of cultural determinism and neo-institutional economics, a proper understanding of the causes of China's dysfunctional market could be arrived at: this round of the marketization in China would be inevitably dysfunctional due to the fact that it was developed under circumstances under which the traditional values (such as the Confucian ideas on benefit and righteousness) have been greatly marginalized as they had been rooted out during the first three decades after the ascendancy of Mao in 1949, and especially during the cultural revolutions of the sixties and after. Hence, there are no inherent cultural and ethical practices which might sustain the healthy development of behaviour and institutions to support and develop the market economy. This paper is not opposed to such arguments, but such arguments do not offer the reasons why traditional ethics could provide the incentives for businesses to maintain their reputation rather than simply deceiving consumers in pursuit of profit. In other words, cultural determinists and neo-institutional economists seem to attribute the causes of dysfunction in the Chinese market economy to a moral vacuum or moral nihilism in Chinese society after the wholesale removal of traditional values during the Maoist era which could have supported market development. This paper, in 
contrast, demonstrates that it is questionable to say the poverty of normative social norms is the factor causing the disorder but one needs to realize that during the transition from the Maoist era to the post-Mao period, some ethical codes, primarily the ethics of conviction, did persist and continued to guide Chinese people's behaviours, including the provision of the incentives for businessmen to deceive consumers. In summary, this paper places the framework for analysis utilized by cultural determinism and neo-institutional economics into the wider context of Chinese society and change.

Thus far, there is very little literature from the schools of cultural determinism and neo-institutional economics which consider the inherent ideological and structural associations persisting between the era of Mao and post-Mao Chinese society after 1978, which, judging by this paper, is the key to understanding the causes of dysfunction of today's Chinese market economy.

What sets this paper apart from these other works is not its opposition to the methodologies utilized by cultural determinists and neo-institutional economists but to consider the contrasting ethics of politicians in the democratic state and the totalitarian one and to contextually examine the different moral foundations between the Chinese market economy, Smith's sense of a market economy and a Confucian definition. Therefore, the present economic system in China has been driven by economic centralism combined with the legacy of the philosophical core of communist ideology which is, in essence, representative of Weber's ethic of conviction in this context. Such ideological inheritance could be treated as one of the most important reasons causing the dysfunction in China's market economy.

\section{A General Introduction to the Concept of the Ethics of Conviction and Responsibility Propounded by Max Weber}

In his classic essay Politics as a Vocation, Max Weber identified two different types of ethics in politics: the ethics of conviction (Gesinnungsethik) and responsibility (Verantwortungsethik) (Weber 1919). In propounding the ethic of conviction, Weber (1919, p. 121) posited:

If an action of good intent leads to bad results, then, in the actor's eyes, not he but the world, or the stupidity of other men, or God's will who made them thus, is responsible for the evil...The believer in an ethic of conviction feels 'responsible' only for seeing to it that the flame of pure intentions is not quelched: for example, the flame of protesting against the injustice of the social order.

According to this statement, one may argue that the ethic of conviction leads people to be responsible only for legitimizing the intentions of their actions rather than taking the possible risks or negative effects incurred from such actions into account. In addition, Bell's analysis of the ethic of conviction is pertinent: "the ethic of conviction does not take into account the consequences of actions; it is not concerned with the opinions of others and although it may attract elaborate justifications, it is sealed off from the real world. Those who believe in the ethic of 
conviction only feel responsible for seeing to it that the flame of pure intention is not lowered; its practitioners have a heroic vision and they are not compromisers (Bell 1985 , p. 1). Hence, the definition of ethic of conviction is as follows:

Definition 1 Those who believe in the ethic of conviction do not take into account the negative consequences of actions; they are not concerned with the opinions of other people as well as the legitimacy of the means being adopted to the attaining of the goals as long as the purpose of an action is justified. An ultimate end is always set to justify the faithful but potentially illegitimate means.

Considering the relationship between the ethics of conviction and responsibility, Weber (1919, p. 124) further argued that:

We must be clear about the fact that all ethically oriented conduct may be guided by one of two fundamentally differing and irreconcilably opposed maxims: conduct can be oriented to an 'ethic of ultimate ends' or to an 'ethic of responsibility.' This is not to say that an ethic of ultimate ends is identical with irresponsibility, or that an ethic of responsibility is identical with unprincipled opportunism. Naturally nobody says that. However, there is a potentially abysmal contrast between conduct that follows the maxim of an ethic of ultimate ends-that is, in religious terms, 'The Christian does rightly and leaves the results with the Lord'-and conduct that follows the maxim of an ethic of responsibility, in which case one has to give an account to the foreseeable results of one's action.

In accordance with this statement, one could infer that the ethic of responsibility has more in common with a utilitarian morality which is more suited to the efficient running of modern politics in democratic states. Also, as argued by Bell (1985, p. 1): "the ethic of responsibility is the utilitarian morality of those who judiciously weigh up ends and means in a search for effectiveness (even though this is a somewhat messy process) and it is supposedly the morality of realists. It is the ability to find suitable means to the attaining of particular goals".

Definition 2 The ethic of responsibility is the utilitarian morality of those who balance the ends, means and negative effect of an intended action in order to evaluate its potential efficacy. The means itself has to be legitimized to attain some multiple and particular goals. An ultimate end is not set so an overarching goal that might encourage illegitimate means is precluded.

If one applies Weber's two concepts of ethical behaviour into the sphere of the of market economy, it enables us to posit some possible variations: if the moral foundation of a market economy were to be guided by the ethic of conviction and assumes the creation of wealth as an ultimate end, then firms are more likely to adopt illegal means to achieve such an end, irrespective of the negative consequences. In contrast, if the ethics of a market economy are based upon the ethic of responsibility, then, in order to reconcile the ends with the appropriate means, firms are more inclined to want to legitimize the means and thus corrupt behaviours are avoided. 


\section{The Persistence of the Ethic of Conviction During the Transformation in China from Communism to Economic Centralism}

One of the most obvious characteristics of the development strategies adopted during the Maoist era, as argued by Gu (2013), is the incompatibility between means and ends. Before the opening-up policies in 1978, communist society was characterized by pure altruism and asceticism was deemed as the ultimate goal by official state policies. In order to achieve this goal, the political campaigns, which would be viewed as unconstitutional in a democracy, in particular The Great Leap Forward, Anti-Rightist movement as well as The Cultural Revolution, were adopted by the government due to their conviction in the absolute primacy of the continued development of Maoist communism. Ruling leaders thought their sole purpose was to facilitate China's transition to communism and this sole aim and purpose was undoubtedly legitimized even though the means could be illegitimate. One could argue that at least in the sphere of politics, the national ideologies and development strategies of Mao's era exhibited a strong strain of the ethic of conviction as the political rulers did not feel it is necessary to take into account the negative consequences of their actions: notably, the death of millions of people as a consequence of The Great Leap Forward.

After the death of Mao, Deng Xiaoping launched the "open-door" policies in 1978. There followed a massive ideological shift in Chinese society. Specifically, the state ideology shifted to a doctrine focused solely on economic development, transforming from the dominance of asceticism and altruism in Mao's era to the pursuit of money and material interests. Kenneth Lieberthal has described this drastic change: "The guiding ideology of [China] has shifted from one of social purification to one of unvarnished pursuit of income" (Lieberthal 1995, p. 268). However, on closer inspection it is apparent that there are overlaps and similarities between the communist ideology during Mao's era and the economic centralist ideology after the open-door policy in 1978: essentially, the ethic of conviction persists across both eras. This is because, according to two famous quotations from Deng Xiaoping:

(1) Development is the hard way.

(2) Being rich is an achievement to be proud of.

One can see that economic growth by encouraging the individual to create wealth with the bulwark of economic centralist ideology replaces Maoist ideology in terms of the construction of communist society. Indeed, it transforms to a sort of ultimate goal for national ideology in China in the same way communist ideology did during Mao's era, ultimately, providing the justification for economic agents in the market to adopt illegitimate means during the process of a transaction. There is no need for economic agents to be concerned about the negative consequences brought by their illegal/immoral actions (such as deceiving the consumers) as their purpose of creating wealth is legitimized by the national ideology. Zhen's analysis is relevant here to support the aforementioned argument: 
Deng Xiaoping's 'southern tour' in the early 1990s had brought a new wave of ideological liberation. In order to establish the status of the market economy, Deng Xiaoping put forward the policy of 'no argument'. However, a kind of new ideology quickly emerged in China behind 'no argument'; namely, the 'economic only' doctrine, which is the pursuit of wealth by all means. The 'economic only' doctrine quickly prompted the transformation of Chinese society from an ideological society based on traditional non-material factors, to a society which put material interests first. The main style of state governance has also transformed in ways that mean it highly relies on means to meet material interests (Zhen 2007, p. 1).

According to Zhen's argument, especially his definition of the economic only doctrine which is the pursuit of wealth by all means, it could be posited that the economic only doctrine policies initiated by the Chinese government mirrored how the ethic of conviction was dominant during the Maoist era. This is due to the fact that the ethic of conviction, according to the definition proposed in this paper, could urge believers to achieve the ultimate end by all and any kinds of means, including illegal ones. It is clear that the Chinese government still set an ultimate goal as the core value pursuit of its national ideology which now becomes rapid economic growth through stimulating people's desire for wealth. It could be demonstrated that even though there occured a massive shift of national ideology in China after the death of Mao, the "deep structure" of this ideology remains the same as during the Mao era: both communist and economic centralist ideology have set the ultimate goals and in order to achieve these goals, arbitrary and all means could be utilized as far as the purposes of the means are justified. This explains why the ethic of conviction has been prevailing in Chinese society since the Maoist era and continues to play an important role in terms of guiding the majority of Chinese people's economic behaviours. The current dysfunction existing in China's market economy could be interpreted as an illustration of how the ethic of conviction distorted the basic business norms, rules and practices such as never infringing upon the customer's right by using unscrupulous behaviour. The following table illustrates how such persistence exits:

\begin{tabular}{lll}
\hline & Means & Ultimate goal \\
\hline $\begin{array}{c}\text { Maoist era } \\
(1949-1976)\end{array}$ & $\begin{array}{c}\text { Different types of unconstitutional political movements, } \\
\text { proletariat dictatorship }\end{array}$ & Communist society \\
$\begin{array}{c}\text { Post-Mao era } \\
(1978-)\end{array}$ & $\begin{array}{c}\text { Illegal actions such as deceiving consumers, corruption, } \\
\text { rent-seeking behaviours }\end{array}$ & $\begin{array}{c}\text { Economic growth, } \\
\text { wealth creation }\end{array}$ \\
\hline
\end{tabular}

Also, based on the analysis above, Proposition 1 could be obtained:

Proposition 1 The moral foundation of the Chinese market economy is based on the ethic of conviction and this distorts the incentives for firms to provide highquality goods and services. 


\section{A Comparative Study of the Chinese Market Economy: Smith's Sense of a Market Economy and a Confucian Sense of a Market Economy in Terms of Their Respective Ethical and Moral Foundations}

\subsection{Smith's Sense of a Market Economy in Terms of its Ethical and Moral Foundations}

One may argue that self-interest is the core of Smith's sense of a market economy. His famous quotation:

...it is not from the benevolence of the butcher, the brewer, or the baker that we expect our dinner, but from their regard to their own interest. We address ourselves, not to their humanity but to their self-love, and never talk to them of our own necessities but of their advantages. (Smith 2010, p. 13)

This reference highlights the fact that for Smith the only means to economic growth is through encouraging individuals to create wealth through maximizing their selfinterest. Nonetheless, this paper shows that there are some preconditions in terms of ethics and morality which have to be satisfied so that the role of self-interest can indeed work to create a properly functioning market economy, so the perspective given above by Adam Smith has to be considered within his ideas about the proper ethical and moral foundations for markets to perform effectively for the whole. That is to say, it is a misunderstanding if one puts egoism as an equivalent term to that of the role of self-interest propounded by Adam Smith. Sen (1997, p. 11) highlights the following points from thoroughly examining the ideas presented in Smith's text Moral Sentiment:

“...a promising- and versatile-framework is that of multiple objectives, which can very plausibly include the search for profits as one important objective among others. The other objectives can compete with profit maximization in influencing business behaviour, can sometimes work as constraints reflecting established moral codes and social conventions. The force of profit maximization may have to work subject to these constraints." Sen clarifies that Adam Smith did not regard profit maximization as the sole objective of the market economy and one has to go beyond such a one-dimensional account of the nature of a free market economy. It is worth mentioning that apart from being an economics professor in Glasgow University, Adam Smith also taught moral philosophy there. This implies that it is very hard for someone to believe Adam Smith did not pay any attention to the moral foundation of a free market economy. According to the research by Etzrodt (2008), Adam Smith was a Neo-Calvinist who was deeply influenced by synergies between business ethics and protestant ethics. Bonino (2003) thinks that protestant ethics lead to economic agents believing that profit could be used to meet our needs, but profit is definitely not an absolute end which I can pursue irrespective of the 'common good' of the society as a whole, and society has a right to call me to account both for the legitimacy of its production and for the use of the profit in terms of improving the welfare of 
society. It is clear that for Smith accumulating wealth is what drives the market, but he is clear in his belief that accumulating wealth is not the only goal or even the ultimate goal of the market. It is only a means to other more essential goals. From the standpoint of Adam Smith, creating wealth ought not to be treated as the ultimate goal and this is quite different from the philosophical foundation of the national ideology contended by the present Chinese government economic centralism-which regards creating wealth as the ultimate end of each individual economic agent.

In his essay in "Business Ethics" Michael Boylan states:

"While Smith points out the obvious fact that self-interest is a great motivating factor and shows that self-interest is a great incentive to get engaged in market activity, we should not confuse that incentive with the real purpose of the market. To confuse incentives with purposes is similar to confusing the engine of a plane with the destination of a plane. The engine is what drives you to your goal. It is not the goal. The goal of markets is the production and exchange of goods and services. For any market to succeed, there need to be sectors which provide services necessary for the effective functioning of the market. There must be producers, consumers, traders, and any number of other actors fulfilling the roles necessary to have a vibrant and healthy market. Corporations or sectors of the economy can only survive in the long run if they provide a good or service that is needed" (Boylan 2014, p. 140). It could be argued that Smith's sense of the moral foundation of a market economy refers to the ideas that corporations ought to be not only responsible for their shareholders but also the stakeholders including their workers, vendors, suppliers and customers as well as the community surrounding the business.

From this perspective, Smith's sense of the moral foundation of a free market economy resembles the definition of the ethic of responsibility stated in this paper as ethical responsibility stresses the need to pay attention to corporate reputation while obtaining profits. Moreover, these two types of moral codes enable people to take more responsibility for the actions they take and one has to be conscious about the risks caused by the actions. Thus, in accordance with Smith's sense of the ethical and moral foundation of a free market economy, taking unscrupulous actions such as deceiving consumers to make abnormal profits is not acceptable as it would harm the market, the common good and society in general. Given the fact that making abnormal profits through infringing consumer rights might entail a huge risks such as punishment by the legal system, action taken by consumers or other third-party legal action, in order to avoid these risks businessmen have to be more inclined to maintain the reputation of the firms. Thus, the following proposition:

Proposition 2 Smith's sense of the moral foundation of a market economy is based on the ethic of responsibility which makes firms more inclined to maintain their reputation. 


\subsection{A Confucian Sense of the Market Economy in Relation to its Ethical and Moral Foundations}

Regarding the ethical and moral foundations of the market economy in regions influenced by Confucianism, there are several pieces of emergent research worth mentioning. From the book "Culture and Economy: the shaping of capitalism in Eastern Asia", the author argued that profit was problematic only to the extent that it narrowed the advantage of the individual rather than yielding benefits for all of society. Confucianism places righteousness before profit in order to regulate profit taking, not to discourage it (Brook and Luong 1997). Confucian ideas on business ethics state that firms should strike a balance between righteousness (which is the maintenance of a firm's reputation) and profit maximization. It appears logical to argue that Smith's sense of the ethical and moral foundation of a market economy and a Confucian one are similar as both argue that a balance ought to be struck between the common good of a society and individual self-interest. This implies that firms guided by a Confucian conception of righteousness and profit would be very concerned with the negative consequences brought by the illegal profit-seeking behaviours which may harm the society as a whole. From this viewpoint, Confucian conceptions of righteousness (yi 义) and profit (li 利) overlap with the ethic of responsibility prevalent in business ethics. Jacobs et al. (1995) further made the point that several East Asian governments, including Taiwan, Singapore, South Korea and Japan have tried to impose the principle of Yi (righteousness) upon the daily business management. In this way, a business could obtain long-term profit while eliminating the destructive consequences of illegal profit-seeking and unfair competition. Such principles have helped generate a new ethical industrial discourse for East Asia.

Suffice to say that although cultural determinism and neo-institutional economics provide similar approaches to examine the causes of the dysfunction of the current Chinese market economy, they do not further ask the question of what is actually the ethical foundation of a market economy from a Confucian perspective, and they only focus on how the removal of traditional ethics and morals during the Mao era caused a moral vacuum in Chinese society and subsequently its relatively dysfunctional economy. Instead, our paper verifies that the Confucian conception of righteousness in balancing the drive for profit has effectively maintained the ethical norms for the businesses and entrepreneurs in East Asian areas. Hence, we have the following proposition:

Proposition 3 A Confucian sense of the ethical and moral foundation of a market economy is based on the ethic of responsibility which makes firms less likely to deceive consumers.

\section{Firm Size as an Amplification Mechanism of the Ethic of Conviction}

One of the puzzles this paper tries to solve concerns why the dysfunction and disorder in the Chinese market economy is more severe than other advanced Western economies or other East Asian economies. One possible explanation, as 
described previously, is because the Chinese economy is endowed with different ethical and moral foundations compared with other economies. The legacy of the ethic of conviction from the Maoist era has distorted the incentives for firms to maintain their reputation. However, it seems that the prevailing existence of a large number of small-sized firms further amplifies the mechanism through which the ethic of conviction negatively affects the reputation of firms. Zhang argues that: "What we have observed is that, except for a few state-owned monopolies (such as petroleum, railway, aviation and bank), most Chinese industries have contained too many small atomic enterprises, participants with no dominant status. From the perspective of the number of enterprises, the Chinese economy is perhaps the most severely 'competitive' economy" in the world (Zhang 2002, p. 61). ${ }^{3}$ Firms of a larger size tend to deceive consumers less as their established branding effect provides them a monitoring mechanism through which they would be easily punished if they are found to be unscrupulous in their dealings with consumers. Likewise, firms of a smaller size tend to conduct unscrupulous behaviour more often as their less established branding effect may preclude them from punishment.

Some empirical studies have supported our argument. For instance, using a sample of 630 privately owned firms in China, Cui et al. (2015) found that there exists the negative relationship between the commitment CSR (Corporate Social Responsibility) and average sales growth in small firms (100 or fewer employees). But the relationship is positive for the larger firms (1000 or more employees). Their empirical findings imply that firms of a smaller size tend to deceive consumers to a greater extent. The relevance of firm size in explaining the extent to which firms deceive consumers in China provides a very good insight in terms of understanding why the prevalence of small-sized firms in the Chinese economy could make businessmen even more committed to the ethic of conviction as there is no such branding effect meaning they are not easily identified and punished (probably by the institutions of the state especially the legal system) after they conduct unscrupulous behaviours. Thus, small firms adhere to a "fast buck" mentality to the detriment of the consumer.

\section{A Quantitative Framework}

\subsection{Isoprofit Curve}

From the firm's point of view, it is assumed that the effort made by firms to establish the reputation is the $x$-axis, whereas $y$-axis is the effort made by firms to deceive consumers. Here we use these two types of effort as the proxy variables for the ethics of responsibility and morality of conviction.

\footnotetext{
${ }^{3}$ Compared with the West or even with many developing countries, the concentration rate of the majorities of China's industries is much lower. For example, in the 15 manufacturing sectors, only the oil sector has four companies which account for more than $40 \%$ of the concentration rate, three sectors are between 20 and 30\%, while the remaining 11 sectors are all under 20\% (5 of them are less than 8\%). Quoted from 'Logic of the Market', Zhang (2002, pp. 61-62), Shanghai People's Publishing House.
} 
Assumption 1 In the long term, the establishment of good reputation could increase firms' profits, whereas deceiving consumers would reduce the profits. Given the level of the effort made by firms to deceive the consumers, the higher the effort in maintaining the firms' reputation (i.e. higher level of morality of responsibility), higher level of profits would be yielded and the corresponding firms' size would become larger as well.

Assumption 2 The marginal substitution rate $\left(\frac{\Delta y}{\Delta x}\right)$ between efforts in deceiving consumers and efforts in maintaining the reputation of firms is decreasing.

Assumption 3 There exists the upper bound of the effort in deceiving consumers. For higher level of profits and larger size of firms, the upper bound is lower and vice versa for the less profitable and smaller-sized firms.

The rationale behind Assumption 3 is as follows. The firms with larger size have the brand effect implying that they would be punished in a very short time if they make effort in deceiving consumers. As a result, their profits would be largely undermined. The upper bound of the efforts in deceiving consumers for larger firms is thus lower. In contrast, there is no brand effect for the firms with smaller size, so the upper bound of the efforts in deceiving consumers is higher.

The intuition of upper bound is that there exists two points lying on the asymptote which is parallel to the $x$-axis. These two points correspond to the same level of $y$ but with values of $x$. In other words, when the efforts made by firms to deceive consumers reach the upper bound $y$, the profitability of firms would not be changed regardless of whether firms continue to increase or decrease the efforts in maintaining the reputation.

Thus, we have two isoprofit curves $\pi=\pi 1(x, y)$ and $\pi=\pi 2(x, y)$ as follows:

Proposition 4 When the cross-point of a firm's isoprofit curve on the $x$-axis is further from the origin, this firm is more profitable.

Proof of Proposition 4 From Fig. 1, if the effort in deceiving consumers is 0 , then it implies that $x_{1}<x_{2}$. According to Assumption 1, we know that firm 1 with smaller

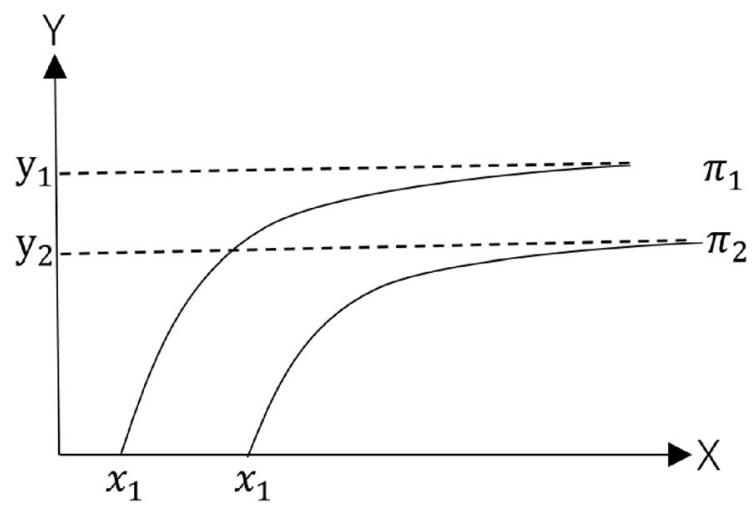

Fig. 1 Isoprofit curves 
size is less profitable. Then it could be demonstrated that when the cross-point of a firm's isoprofit curve on the $x$-axis is further from the origin, this firm is more profitable.

Proposition 5 Two isoprofit curves have no cross-points.

Proof of Proposition 5 Since the cross-point of the isoprofit curve of the less profitable firm on the axis is closer to the origin, implying that its firm size is smaller. According to Assumption 3, the upper bound of the effort in deceiving consumers made by smaller firms is higher that of firms with larger size. It is therefore easy to see that the isoprofit curve of the less profitable and smaller firms must lie upward left direction compared with the more profitable and larger firms. So two isoprofit curves would not intercept with each other.

\subsection{Isocost Curve}

Assumption 4 For a particular society, the decreased level of cost caused by the one-unit increase in the effort in deceiving consumers and the increased level of cost caused by the one-unit increase in the effort in maintaining firm's reputation are, respectively, denoted by $P_{d}$ and $P_{c}$.

As we know that the reason of why firms tend to deceive consumers is because it could reduce the level of cost as maintaining the reputation requires firms to invest huge amount of money on branding as well as advertising. So the set of the isocost curves could be represented as follows:

$$
C=C(x, y)=P_{c} x-P_{d} y
$$

One of the isocost curves in this set is

$$
C_{0}=P_{c} x-P_{d} y
$$

when $C_{0}<0$ the intercept of this isocost curve on the $y$-axis is written as $y=-\frac{C_{0}}{P_{d}}$, when $C_{0}>0$, the isocost curve has the intercept on $x$-axis, which is denoted by $x=-\frac{C_{0}}{P_{c}}$.

Assumption 5 When $P_{d} y<P_{c} x$, this implies that the level of the increased cost caused by the effort in maintaining reputation of firms' is larger than the level of the decreased cost caused by the effort in deceiving consumers. When this happens, then firms are more inclined to establish the good reputation and vice versa for firms that are more prone to deceive consumers when $P_{d} y>P_{c} x$.

The isocost curve is shown as follows: 


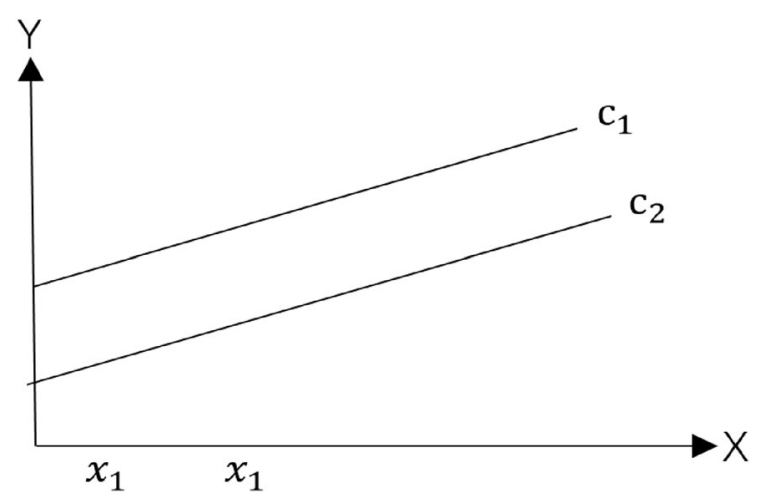

From Assumption 4, we know that the gradient of each isocost curve is the same, but with different intercepts. From Assumption 5, we know that when isocost curve has the intercept on the $y$-axis, firms tend to be more inclined to deceive consumers. When isocost curve has the intercept on the $x$-axis, firms tend to be more committed to their reputation.

\subsection{Equilibrium}

Proposition 6 When the isocost curves and isoprofit curves are tangential to each other, the profits are maximized. The tangential point represents the optimal combination between effort in reputation building and effort in deception behaviour.

Proof of Proposition 6 Given the constraint of $C_{0}=P_{c} x-P_{d} y$, we would maximize the objective function $\pi=\pi(x, y)$ such that we obtain the optimal solution for the efforts level.

We construct the following Lagrangian function, where $t$ is the Lagrangian multiplier.

$$
N(x, y, t)=\pi(x, y)+t\left(C_{0}-P_{c} x+P_{d} y\right)
$$

The first-order condition for the profit maximizing is:

$$
\begin{gathered}
\frac{\partial N}{\partial x}=\frac{\partial \pi}{\partial x}-t P_{c}=0 \\
\frac{\partial N}{\partial y}=\frac{\partial \pi}{\partial y}+t P_{d}=0 \\
\frac{\partial N}{\partial t}=C_{0}-P_{c} x+P_{d} y=0
\end{gathered}
$$

From (1) and (2), we obtain that

$$
\frac{\partial \pi / \partial x}{\partial \pi / \partial y}=\frac{M \pi_{x}}{M \pi_{y}}=-\frac{P_{c}}{P_{d}}
$$


On the isoprofit curve, we have $M \pi_{x} \cdot d x+M \pi_{y} \cdot d y=0$, which means

$$
\frac{M \pi_{x}}{M \pi_{y}}=-\frac{d y}{d x}
$$

Plugging (4) into (5), we obtain that:

$$
\frac{d y}{d x}=\frac{P_{c}}{P_{d}}
$$

When the isocost curve is tangential to the isoprofit curve, the profit is maximized and the optimal level of two types of efforts is shown as follows:

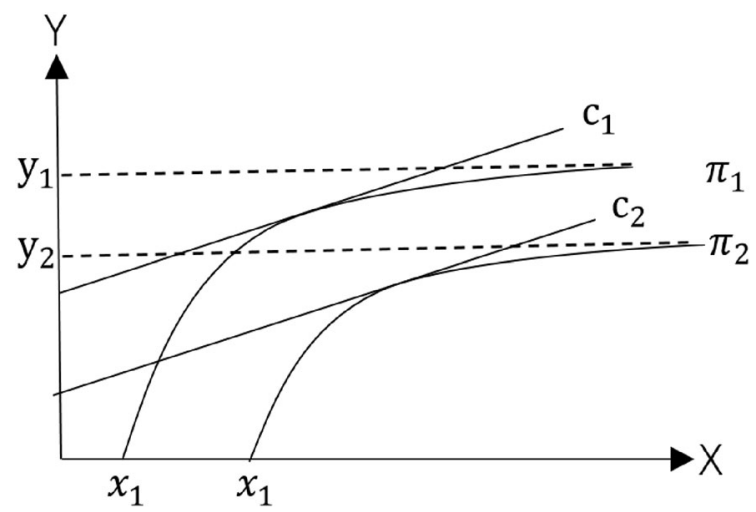

Theorem 1 Smaller firms tend to deceive consumers more often, thus exhibiting higher level of morality of conviction. Larger firms tend to build reputation more often, thus exhibiting higher level of morality of responsibility.

Proof of Theorem 1 The isoprofit curve of smaller firms is closer to the origin and the upper bound of the efforts in deception behaviour is higher; this leads to the fact that it is much more likely for isocost curves to have the intercepts on the $y$-axis. Thus, according to Assumption 5, firms with smaller size tend to deceive consumers more often and exhibit higher level of morality of conviction.

In contrast, the isoprofit curve of larger firms is further to the origin and the upper bound of the efforts in deception behaviour is lower; this leads to the fact that it is much more likely for isocost curves to have the intercept on the $\mathrm{x}$-axis, so from Assumption 5, larger firms tend to make more effort on reputation building, thus generating higher level of morality of responsibility.

Assumption 6 In a society where ethics of responsibility prevails, the decreased level of cost caused by one-unit increase in effort of deceiving behaviour is lower, that is, lower value of $P_{d}$, In a society where ethics of conviction prevails, the decreased level of cost caused by one-unit increase in effort of deceiving behaviour is higher, that is, higher value of $P_{d}$. 
Theorem 2 In a society where ethics of responsibility prevails, firms tend to build reputation more often. In a society where ethics of conviction prevails, firms tend to conduct deceiving behaviours towards consumers.

Proof of Theorem 2 In a society where ethics of responsibility prevails, the value of $P_{d}$ is smaller. Given that $P_{c}$ remains unchanged, then the gradient of its isocost curve is bigger, the intercept is thus more likely to lie on the $x$-axis after the isocost curve is tangential to the isoprofit curve. In other words, firms are more inclined to build the reputation. In a society where ethics of conviction prevails, the value of $P_{d}$ is larger. Given that $P_{c}$ remains unchanged, then the gradient of its isocost curve is smaller, the intercept is thus more likely to lie on the $y$-axis after the isocost curve is tangential to the isoprofit curve. This implies firms in an economy with ethics of conviction prevail as its moral foundation will be more inclined to deceive consumers.

\section{Conclusion}

The ethic of conviction, realized as economic centralism, forms a continued "deep structure" in the current national ideology of China which has resulted in a different ethical and moral foundation of the market economy compared with advanced economies where the ethic of responsibility dominates. These other advanced economies are influenced by either Smith's sense of a market economy or a Confucian sense of a market economy. Max Weber's classification of the two types of ethics of politicians enables us to clarify what has actually caused the dysfunction and disorder of the current Chinese market economy and continues to affect its operation. It must be noted that though the perspectives of cultural determinism or neo-institutional economics have partially pointed out that traditional ethics ought to play a more important role in terms of reshaping economic behaviours in China, from creating wealth by all means to creating wealth by appropriate means: however, they do not contextualize the factors causing the dysfunction of the Chinese market economy, namely the continued "deep structure" of the ethic of conviction pervading national ideology and political doctrine and actions from the Mao era right through to the present day.

Open Access This article is distributed under the terms of the Creative Commons Attribution 4.0 International License (http://creativecommons.org/licenses/by/4.0/), which permits unrestricted use, distribution, and reproduction in any medium, provided you give appropriate credit to the original author(s) and the source, provide a link to the Creative Commons license, and indicate if changes were made.

\section{References}

Barro, R., and R.M. McCleary. 2003. Religion and economic growth. American Sociological Review 68 (5):760-781.

Bell, David Scott. 1985. The conservative government, 1979-1984: An interim report. Croom Helm Ltd: Routledge.

Bonion, J.M. 2003. Religious resources for business ethics: A protestant view. Latin American Business Review 4 (4): 105-118. 
Boylan, Michael. 2014. Business ethics. Hoboken: Wiley.

Brook, Timothy, and Hy V. Luong. 1997. Culture and economy: The shaping of capitalism in Eastern Asia. Ann Arbor: The University of Michigan Press.

Cui, Zhiyu, Xiaoya Liang, and Xiongwen Lu. 2015. Prize or price? Corporate social responsibility commitment and sales performance in the Chinese private sector. Management and Organization Review 11 (1): 25-44.

Deng, Zhenglai. 2011. Where Chinese jurisprudence will go: Constructing the era outline of the ideal picture of Chinese law. Beijing: Commercial Press.

Etzrodt, Christian. 2008. Weber's protestant-ethic thesis, the critics, and Adam Smith. Marx Weber Studies 2008: 49-78.

Gong, Qun. 2006. Moral value orientation of Singapore. Shanghai Normal University Journal: Philosophy and Social Sciences 5.

Gu, Zhun. 2013. From idealism to empiricism. Beijing: Guangming Daily Press.

Huang, Chun-Chieh. 2015. East Asian Confucianism: Texts in context. Taipei: National Taiwan University Press.

Jacobs, Laurence, Gao Guopei, and Paul Herbig. 1995. Confucian roots in China: A force for today's business. Management Decision 33 (10): 29-34.

Liberthal, Kenneth. 1995. Governing China, from revolution through reform. New York: W.W. North\&Company, INC.

MacFarquhar, R. 1985. The post-confucian challenge. In Korea: Past, present and future. Queenstown, MD: Aspen Institute for Humanistic Studies.

Morishima, Michio. 1982. Why Japan succeeded?-Western technology and the Japanese ethos. Cambridge: Cambridge University Press.

North, Douglas C. 1990. Institutions, institutional change and economic performance. Cambridge: Cambridge University Press.

Sen, Amartya. 1997. Economics, business principles and moral sentiments. Business Ethics Quarterly 7 (3): $5-15$.

Smith, Adam. 2010. The Theory of Moral Sentiment, Anv ed. London: Penguin Classics.

Weber, Marx. 1946. The politics as vocation, From Marx Weber, 1919, tr and ed. by H.H. Gerth and C. Wright Mills. New York: Free Press.

Yao, Zhongqiu. 2011. Finding the golden mean: When freedom encounters tradition. Kuala Lumpur: Chinese Press.

Zhang, Weiying. 2002. Reputation basis of legal system. Economic Research Journal 1: 3-13.

Zhen, Yongnian. 2007. Economy-centrism Overheating. China difficult to Reconstruct Ideology': New Express newspaper.

Zou, H. 1993. Economic growth, the capitalist spirit and thrift. Jounral of Economic Research. 56-64.

Huangnan Shen Jim is a Master Student at London School of Economics and Political Science specializing in Economics and Management.

XiaoJie Liu is a Master Student at Sciences Po majoring in Economics. 